\title{
Spiroplasma litorale sp. nov., from Tabanid Flies (Tabanidae: Diptera) in the Southeastern United States
}

\author{
MEGHNAD KONAI, ${ }^{1}$ ROBERT F. WHITCOMB,${ }^{2 *}$ FRANK E. FRENCH,${ }^{3}$ JOSEPH G. TULLY,${ }^{4}$ DAVID L. ROSE, ${ }^{4}$ \\ PATRICIA CARLE, ${ }^{5}$ JOSEPH M. BOVÉ, ${ }^{5}$ KEVIN J. HACKETT, ${ }^{1}$ ROBERTA B. HENEGAR, ${ }^{2}$ \\ TRUMAN B. CLARK, ${ }^{1} \uparrow$ AND DAVID L. WILLIAMSON ${ }^{6}$ \\ Insect Biocontrol Laboratory ${ }^{1}$ and Vegetable Laboratory, ${ }^{2}$ Agricultural Research Service, Beltsville Agricultural \\ Research Center, U.S. Department of Agriculture, Beltsville, Maryland 20705; Department of Biology, Georgia Southern \\ University, Statesboro, Georgia 304603 ; Mycoplasma Section, Laboratory of Molecular Microbiology, National Institute \\ of Allergy and Infectious Diseases, Frederick Cancer Research Facility, Frederick, Maryland 21702 ${ }^{4}$; Laboratoire de \\ Biologie Cellulaire et Moléculaire, Institut Nationale de Recherche Agronomique, 33883 Villenave d'Ornon, France ${ }^{5}$; \\ and Department of Anatomical Sciences, State University of New York, Stony Brook, New York $11794^{6}$
}

\begin{abstract}
Spiroplasma strain $\mathrm{TN}-1^{\mathrm{T}}$ ( $\mathrm{T}=$ type strain), a strain serologically distinct from other spiroplasma species, groups, and subgroups, was isolated from the gut of a horsefly (Tabanus nigrovittatus) from a barrier island off the coast of North Carolina. Related strains were isolated from other Tabanus spp., T. atratus, T. americanus, $T$. gladiator, $T$. lineola, $T$. sulcifrons, and $T$. zythicolor, from coastal Georgia. Cells of strain $T N-1^{T}$ in culture were helical and motile with an average of 5 to 10 helical turns per cell. Electron microscopic studies determined that the cells of strain $\mathrm{TN}-1^{\mathrm{T}}$ were surrounded by a single cytoplasmic membrane, and there was no evidence of a cell wall. The spiroplasma grew well in M1D and SP-4 liquid media. Serum fraction (1\%) medium and conventional horse serum medium also supported growth of strain $\mathrm{TN}-\mathrm{I}^{\mathrm{T}}$. Fried-egg colonies were not produced; instead, the strain produced small diffuse colonies that were surrounded by satellite growth. The optimum temperature for growth was $32^{\circ} \mathrm{C}$, but multiplication was observed at temperatures from 10 to $41^{\circ} \mathrm{C}$. The doubling time at the optimum temperature $\left(32^{\circ} \mathrm{C}\right)$ was $1.6 \mathrm{~h}$. No growth was observed at 5 or $43^{\circ} \mathrm{C}$. Spiroplasma strain $\mathrm{TN}-1^{\mathrm{T}}$ passed through 220 -nm filter pores but failed to pass through 100-nm filter pores. Strain TN-1 ${ }^{\mathrm{T}}$ catabolized glucose but hydrolyzed neither arginine nor urea. The guanine-plus-cytosine content of the DNA was about $25 \pm 1 \mathrm{~mol} \%$, and the genome size was $1,370 \mathrm{kbp}$. Based on results from this study and previously published data, strain TN-1 ${ }^{\mathrm{T}}$ (= ATCC 43211) (group XVIII) is designated the type strain of a new spiroplasma species, Spiroplasma litorale.
\end{abstract}

In 1983, one of us (R.F.W.), while visiting North Carolina's Ocracoke Island, observed that the booth of a campground attendant was besieged, as was the entire island, with innumerable individuals of a green-eyed horsefly, Tabanus nigrovittatus (4). The attendant graciously permitted us to collect a sample of flies, from which spiroplasma strain $\mathrm{TN}-1^{\mathrm{T}}$ ( $\mathrm{T}=$ type strain) was derived. Isolates which have similar serological profiles or which exhibit partial serological cross-reactivity with strain $\mathrm{TN}-1^{\mathrm{T}}$ were subsequently isolated from other Tabanus spp., $T$. atratus, T. americanus, T. gladiator, T. lineola, T. sulcifrons, and T. zythicolor collected from a barrier island off the coast of Georgia or from Bulloch County in Georgia's coastal plain (6, $7,22,23$ ). Strain $\mathrm{TN}-1^{\mathrm{T}}$ has been designated the representative strain of spiroplasma group XVIII (19). In this paper we describe the morphological, physiological, and biochemical properties of strain $\mathrm{TN}-1^{\mathrm{T}}\left(=\mathrm{ATCC} 43211^{\mathrm{T}}\right)$ and designate this strain the representative of a new spiroplasma species, the group XVIII species Spiroplasma litorale.

\section{MATERIALS AND METHODS}

Spiroplasma strains. Strain $\mathrm{TN}-1^{\mathrm{T}}$ was isolated by standard techniques $(3,4$ 12) by one of us (T.B.C.) in M1D medium from the gut of a female green-eyed horsefly ( $T$. nigrovittatus) collected at Ocracoke, N.C. Serologically related isolates were also obtained from the guts of six other tabanid fly species, $T$. americanus, $T$. atratus, $T$. gladiator, $T$. lineola, $T$. sulcifrons, and $T$. zythicolor $(6,7,23)$. Some of the genomic and serological features of the organism have been re-

\footnotetext{
* Corresponding author. Mailing address: Vegetable Laboratory, Range 2, GH 3-1, BARCW, Beltsville, MD 20705. Phone: (301) 5048339. Fax: (301) 504-6017.

$\uparrow$ Deceased.
}

ported previously $(2,19)$. Representative strains of all previously recognized groups $(16,17,19,25,26)$ and subgroups, including the type strains of al previously recognized species, were also employed.

Culture medium and cultivation techniques. Spiroplasma strain $\mathrm{TN}-1^{\mathrm{T}}$ was grown in M1D liquid broth $(20)$ at $30^{\circ} \mathrm{C}$. The culture was filtered and cloned (14) in M1D broth containing $500 \mathrm{U}$ of penicillin per ml. A triply cloned strain was designated $\mathrm{TN}-1^{\mathrm{T}}$ and was subsequently used in characterization studies. Othe culture media used in the study were SP-4, conventional $20 \%$ horse serum medium, and a $1 \%$ bovine serum fraction broth (20). Solid medium was prepared by adding $2.25 \%$ Noble agar (Difco Laboratories, Detroit, Mich.). Agar cultures were incubated at $30^{\circ} \mathrm{C}$ either aerobically or anaerobically in a hydrogen GasPak system (BBL Microbiology Systems, Cockeysville, Md.).

Temperature studies. The temperature requirements of cultures of strain $\mathrm{TN}-1^{\mathrm{T}}$ in the late logarithmic phase in M1D broth were determined as previously described $(10,11)$. Growth was measured at temperatures of $5,10,15,20,25,30$ $32,37,41$, and $43^{\circ} \mathrm{C}$

Filtration. Filtration characteristics were determined in M1D broth by passing logarithmic-phase cultures through filters with 450-, 300-, 220-, and 100-nm pores. Each filtrate, as well as an unfiltered control, was subcultured in a serie of 12 tubes by using 10-fold dilutions and was monitored for growth (14).

Morphological studies. Cells of strain $\mathrm{TN}-1^{\mathrm{T}}$ in M1D broth cultures in the logarithmic phase were examined by dark-field microscopy by using a magnification of $\times 1,250$. Electron microscopic examination of the membrane structure of strain $\mathrm{TN}-1^{\mathrm{T}}$ by standard methods (27) has been described previously (19).

Sterol requirements. Strain $\mathrm{TN}-1^{\mathrm{T}}$ was tested for a sterol requirement by two methods; the growth obtained in a serum-free broth formulation containing various concentrations of cholesterol was assessed, and the ability of the strain to show sustained growth in serum-free or serum-containing broth media $(13,15)$ was determined.

Biochemical and physiological properties. The ability of strain $\mathrm{TN}-1^{\mathrm{T}}$ to utilize glucose, arginine, and urea was assessed by previously described methods $(1,30)$ Serological tests. Antiserum to strain $\mathrm{TN}-1^{\mathrm{T}}$ was raised in rabbits as previously described (29). Hyperimmune antisera to all previously established groups, putative groups, and subgroups $(16,17,19,25,26)$ of Spiroplasma species were taken from reference collections at the Beltsville Agricultural Research Center and the National Institute of Allergy and Infectious Diseases laboratory in Frederick, Md. These antisera and spiroplasma $\mathrm{TN}-1^{\mathrm{T}}$ were tested reciprocally in both metabolism inhibition (28) and spiroplasma deformation tests $(28,29)$. 


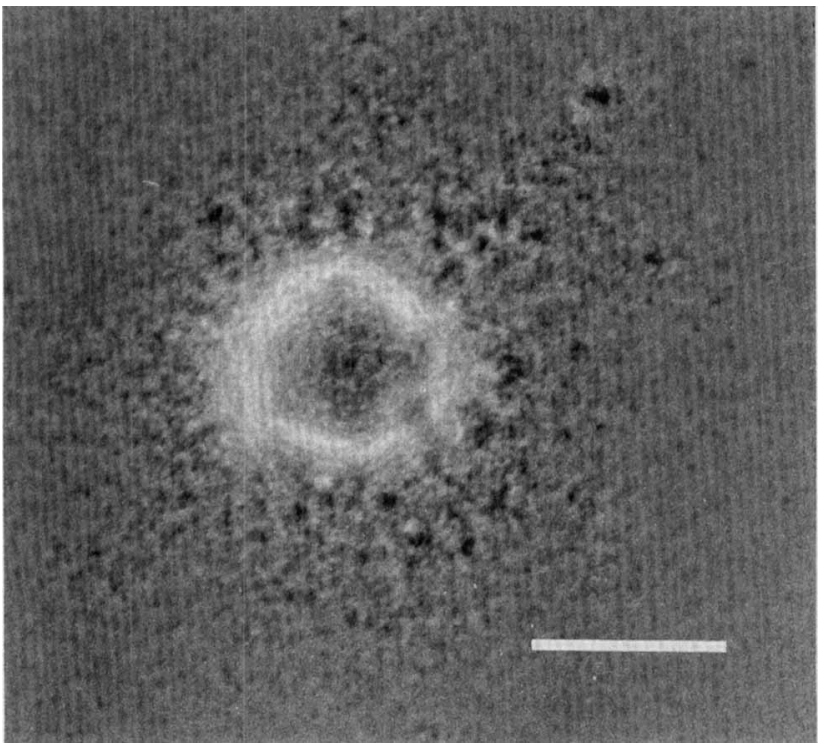

FIG. 1. Colonies of strain TN-1 ${ }^{\mathrm{T}}$ on SP-4 medium supplemented with $2.25 \%$ Noble agar after 3 days of aerobic incubation at $30^{\circ} \mathrm{C}$. Bar $=50 \mu \mathrm{m}$.

Genomic analysis. The guanine-plus-cytosine content of purified DNA of strain $\mathrm{TN}-1^{\mathrm{T}}$ and the genome size of the organism have been reported previously $(2,17,19,25)$

\section{RESULTS AND DISCUSSION}

Cultural and morphological properties. Spiroplasma strain TN-1 ${ }^{\mathrm{T}}$ grew well in M1D and SP-4 broth media containing 500 $\mathrm{U}$ of penicillin per $\mathrm{ml}$. The strain also grew in conventional mycoplasma media containing horse serum or bovine serum fraction. Growth occurred over a temperature range of 10 to $41^{\circ} \mathrm{C}$; optimum growth was observed at $32^{\circ} \mathrm{C}$. The doubling time at the optimum temperature was $1.6 \mathrm{~h}$. Although the organism did not replicate at $5^{\circ} \mathrm{C}$, it was able to retain its helical morphology and remained viable at this temperature. Clark and colleagues (4) reported an optimum temperature of $35^{\circ} \mathrm{C}$ for strain $\mathrm{TN}-1^{\mathrm{T}}$ and noted that this organism grew at $37^{\circ} \mathrm{C}$, but a complete range of temperatures was not tested.

Colonies of spiroplasma strain $\mathrm{TN}-1^{\mathrm{T}}$ on SP-4 medium supplemented with $2.25 \%$ Noble agar grown under aerobic conditions were granular with dense centers, uneven margins, and multiple satellites (Fig. 1). Logarithmic-phase cultures of strain TN-1 ${ }^{\mathrm{T}}$ in M1D and SP-4 media examined by dark-field microscopy contained numerous helical motile filaments. Electron microscopy revealed filamentous cells with no evidence of a cell wall (19). Representative cells were about 200 to $300 \mathrm{~nm}$ in diameter and were surrounded by a single cytoplasmic membrane.

Passage of broth cultures of strain $\mathrm{TN}-1^{\mathrm{T}}$ through 450 - and 300-nm-pore-size membrane filters did not reduce the viable cell titer of a nonfiltered control broth $\left(10^{9}\right.$ color-changing units $/ \mathrm{ml}$ ). The titer of a filtrate obtained after passage through a 220-nm-pore-size membrane filter was reduced about 100 fold (to $10^{7}$ color-changing units $/ \mathrm{ml}$ ); a 100 -nm-pore-size membrane filtrate was free of viable cells.

Sterol requirements and physiological properties. The response of strain $\mathrm{TN}-1^{\mathrm{T}}$ to cholesterol supplementation of serum-free SP-4 medium is shown in Table 1 . No growth was apparent in control base broth devoid of any supplement, but growth was enhanced when 2 to $20 \mu \mathrm{g}$ of cholesterol per $\mathrm{ml}$ was included in the serum-free broth. In experiments to test
TABLE 1. Growth response of strain $\mathrm{TN}-1^{\mathbf{T}}$ to cholesterol

\begin{tabular}{lcc}
\hline \multicolumn{1}{c}{ Medium } & $\begin{array}{c}\text { Cholesterol } \\
\text { concn } \\
(\mu \mathrm{g} / \mathrm{ml})\end{array}$ & $\begin{array}{c}\text { Amt of } \\
\text { protein } \\
(\mathrm{mg} / 100 \mathrm{ml})\end{array}$ \\
\hline M1D & 0 (Control) & $3.06^{a}$ \\
Serum-free base medium with 1\% serum & 0 (Control) & 2.28 \\
$\quad$ fraction & 0 & 0.06 \\
Serum-free base medium alone & 1 & 0.12 \\
Serum-free base medium with cholesterol & 2 & 0.57 \\
& 5 & 0.82 \\
& 10 & 0.76 \\
& 20 & 1.21 \\
\hline
\end{tabular}

${ }^{a}$ Amount of total cell protein obtained from a cell pellet cultivated from 100 $\mathrm{ml}$ of each serum control medium or serum-free base medium supplemented with cholesterol.

the ability of strain $\mathrm{TN}-1^{\mathrm{T}}$ to sustain growth through 23 serial dilutions in serum-free broth, in serum-free broth supplemented with $0.04 \%$ Tween 80 , or in serum-containing media, the organism showed consistent and sustained growth only in medium containing serum. Growth was apparent only in a single 10-fold dilution in each of the two serum-free formulations.

Spiroplasma strain $\mathrm{TN}-1^{\mathrm{T}}$ produced acid from glucose, but no evidence of arginine or urea hydrolysis was observed.

Serological tests. Metabolism inhibition and deformation tests performed with antisera prepared against known and putative Spiroplasma groups and subgroups indicated that strain $\mathrm{TN}-1^{\mathrm{T}}$ was not related serologically to representatives of previously established groups or species or to any of the eight representatives of putative new groups tested. No reciprocal crosses were observed in either test. One-way crosses were observed with 11 groups or putative groups when antiserum against strain $\mathrm{TN}-1^{\mathrm{T}}$ was reacted with heterologous antigen (Table 2). When strain $\mathrm{TN}-1^{\mathrm{T}}$ antigen was tested against heterologous sera, a low-level one-way cross-reaction was observed with strain PALS-1 (an ungrouped representative of a putative new group) in deformation tests. No other crossreactions were observed.

Genome size and DNA base composition. The genome size of strain $\mathrm{TN}-1^{\mathrm{T}}$ was found to be $1,370 \mathrm{kbp}$ by pulsed-field gel electrophoresis (2). The base composition (guanine-plus-cytosine content) of the DNA of strain $\mathrm{TN}-1^{\mathrm{T}}$ was $25 \pm 1 \mathrm{~mol} \%$ (19).

Habitat. The genus Spiroplasma offers a rich opportunity to study the ecology of microorganisms associated with insects (3, 8). Strain $\mathrm{TN}-1^{\mathrm{T}}$ described here was isolated from the gut of the horsefly $T$. nigrovittatus from a barrier island, Ocracoke Island, N.C. Strain TN- ${ }^{\mathrm{T}}$ has not been studied as an insect pathogen. Hundreds of spiroplasma cultures have been obtained from tabanids collected on the coastal plains from Florida to Nova Scotia and in the Rocky Mountains from Montana to New Mexico. Other sites of isolation include Vermont and Texas. The most extensive survey was performed from 1987 to 1994 in Bulloch County, Ga., some $80 \mathrm{~km}$ from the Atlantic Ocean. Cultures closely related serologically to strain $\mathrm{TN}-1^{\mathrm{T}}$ were isolated from six other Tabanus species $(4-7,22,23)$. Four isolates were obtained from $T$. americanus from Bulloch County, Ga., and Johnston County, N.C.; eight cultures were obtained from $T$. gladiator from Bulloch County, Ga.; nine isolates were obtained from $T$. lineola from Bulloch and Camden Counties, Ga.; one isolate was obtained from $T$. sulcifrons from Bulloch County, $\mathrm{Ga}$; and one isolate was obtained from T. zythicolor from Camden County, Ga. A closely related 
TABLE 2. Serological reactions and cross-reactions of strain TN-1 ${ }^{\mathrm{T}}$ in deformation and metabolism inhibition serological tests ${ }^{a}$

\begin{tabular}{|c|c|c|c|c|c|}
\hline \multirow{3}{*}{ Group } & \multirow{3}{*}{ Strain } & \multicolumn{4}{|c|}{ Titer in: } \\
\hline & & \multicolumn{2}{|c|}{ Spiroplasma deformation test } & \multicolumn{2}{|c|}{ Metabolism inhibition test } \\
\hline & & Antiserum & Antigen & Antiserum & Antigen \\
\hline I-8 & P40 & $0^{b}$ & $0^{b}$ & $162^{c}$ & $0^{c}$ \\
\hline II & DW-1 & 40 & 0 & 18 & 0 \\
\hline IV & B31 & 0 & 0 & 18 & 0 \\
\hline VII & MQ-1 & 0 & 0 & 54 & 0 \\
\hline VIII-1 & EA-1 & 0 & 0 & 486 & 0 \\
\hline IX & $\mathrm{CN}-5$ & 40 & 0 & 0 & 0 \\
\hline XVIII & $\mathrm{TN}-1^{\mathrm{T}}$ & $2,560^{d}$ & 2,560 & $>117,000^{d}$ & $>117,000$ \\
\hline XIX & PUP-1 & 80 & 0 & 0 & 0 \\
\hline $\mathrm{XX}$ & LD-1 & 160 & 0 & 18 & 0 \\
\hline XXI & W115 & 40 & 0 & 18 & 0 \\
\hline $\mathrm{XXX}$ & BIUS-1 & 0 & 0 & 18 & 0 \\
\hline XXVI & PLHS-1 & 20 & 0 & 162 & 0 \\
\hline XXVIII & PALS-1 & 0 & $40(1,280)^{e}$ & 486 & 0 \\
\hline All others & All others & $<20$ & $<20$ & $<18$ & $<18$ \\
\hline
\end{tabular}

${ }^{a}$ Strain $\mathrm{TN}-1^{\mathrm{T}}$ antigen and antisera were tested in all heterologous combinations against representatives of all known and putative groups and subgroups. Al cross-reactions were negative except those shown. All cross-reactions observed were in one direction only, demonstrating the serological uniqueness of strain TN-1 ${ }^{\mathrm{T}}$

${ }^{b}$ Reciprocal of the endpoint in a deformation test in which the antigen was tested against the homologous antiserum and vice versa.

${ }^{c}$ Reciprocal of the endpoint in a metabolism inhibition test in which the antigen was tested against the homologous antiserum and vice versa.

${ }^{d}$ Homologous titers of strain TN-1 $1^{\mathrm{T}}$ in the test systems. The reactions, obtained once, are listed in each column for completeness.

${ }^{e}$ The value in parentheses is the homologous titer for antisera against which strain TN-1 ${ }^{\mathrm{T}}$ cross-reacted when it was used as the antigen in a heterologous test.

strain, TAAS-2, was isolated from Tabanus atratus from Cumberland Island, Camden County, Ga. A large number of isolates were obtained from $T$. lineola collected in Florida, Georgia, North Carolina, and Maryland. Overall, the spiroplasma infection rate of these flies was about $50 \%$ (7). However, a low prevalence of isolates related to $\mathrm{TN}-1^{\mathrm{T}}$ was indicated by the fact that only $3.9 \%$ (10 of 256) of the isolates obtained from $T$. lineola reacted to $\mathrm{TN}-1^{\mathrm{T}}$ antiserum. Although other spiroplasmas were isolated from $T$. lineola collected during May and June, isolates related to strain $\mathrm{TN}-1^{\mathrm{T}}$ were obtained from flies collected from July to November, thus indicating possible seasonality in carriage by tabanids. Many tabanids belonging to the genera Chrysops and Hybomitra were collected with the Tabanus hosts of $\mathrm{TN}-1^{\mathrm{T}}$, but no strains related to $\mathrm{TN}-1^{\mathrm{T}}$ have been detected in cultures derived from members of these horsefly genera.

Since mixed infections of different spiroplasmas are common (21), strain $\mathrm{TN}-1^{\mathrm{T}}$ may be frequently overgrown by members of other Spiroplasma groups in vivo or in vitro. The occurrence of spiroplasmas in narrow habitats in insects (tabanid fly viscera) has suggested that these microorganisms could be studied in biogeographic terms (24). Clark et al. (4) were unable to isolate any group XVIII spiroplasmas from $T$. nigrovittatus collected in Maryland. Group XVIII spiroplasmas have been found on two barrier islands (Ocracoke Island, N.C., and Cumberland Island, Ga.) and $130 \mathrm{~km}$ inland from the Atlantic coast (Johnston County, N.C.). The restriction of this spiroplasma to the coastal areas of the southeastern United States makes it one of the best-known examples of a geographically limited spiroplasma.

The properties described here for strain $\mathrm{TN}-1^{\mathrm{T}}$ fulfill the proposed criteria of taxonomic nomenclature (9) for species of the class Mollicutes, including the absence of a cell wall, filterability, and penicillin resistance. The inability of this strain to utilize urea, its temperature requirements, and its helicity and motility place the organism in the family Spiroplasmataceae and the genus Spiroplasma (18). Finally, a serological comparison of strain TN- ${ }^{\mathrm{T}}$ with other Spiroplasma species and with other unclassified spiroplasma strains that represent putative new groups demonstrated the uniqueness of the new insect strain. We therefore propose the name Spiroplasma litorale for this organism.

The taxonomic description below summarizes the properties of the organism.

Description of Spiroplasma litorale sp. nov. Spiroplasma litorale (li.to.ra'le. L. neut. adj. litorale, of the shore or coasta area).

Cells are filamentous, helical, and motile, vary from 200 to $300 \mathrm{~nm}$ in diameter, and lack true cell walls. Colonies on solid medium containing $2.25 \%$ Noble agar are granular with dense centers, uneven margins, and multiple satellites and never have a fried-egg appearance.

Chemoorganotroph. Acid is produced from glucose. Hydrolyzes neither arginine nor urea.

Cholesterol or serum is required for growth.

The temperature range for growth is 10 to $41^{\circ} \mathrm{C}$, with optimum growth occurring at $32^{\circ} \mathrm{C}$. The doubling time in M1D medium at the optimum temperature is $1.6 \mathrm{~h}$.

Serologically distinct from previously established Spiroplasma species. Isolated from the gut of $T$. nigrovittatus (Diptera: Tabanidae). Pathogenicity for insects has not been determined.

The guanine-plus-cytosine content of the DNA is $25 \pm 1$ mol\%, as determined by the buoyant density method. The genome size is $1,370 \mathrm{kbp}$.

The type strain is TN-1 (= ATCC 43211).

\section{ACKNOWLEDGMENT}

We thank Jeffrey Buller, College of Liberal Arts and Sciences, Georgia Southern University, Statesboro, for his advice concerning the Latin name for this spiroplasma.

\section{REFERENCES}

1. Aluotto, B. B., R. G. Wittler, C. O. Williams, and J. E. Faber. 1970. Standardized bacteriologic techniques for characterization of Mycoplasma species. Int. J. Syst. Bacteriol. 20:35-58.

2. Carle, P., F. Laigret, J. G. Tully, and J. M. Bové. 1995. Heterogeneity of genome sizes within the genus Spiroplasma. Int. J. Syst. Bacteriol. 45:178181 . 
3. Clark, T. B. 1982. Spiroplasmas: diversity of arthropod reservoirs and hostparasite relationships. Science 212:57-59.

4. Clark, T. B., R. V. Peterson, R. F. Whitcomb, R. B. Henegar, K. J. Hackett and J. G. Tully. 1984. Spiroplasmas in the Tabanidae. Isr. J. Med. Sci. 20:1002-1005.

5. French, F. E., R. F. Whitcomb, D. V. Hagan, J. A. Rafter, M. Konai, and E. A Clark. 1992. Dynamics of spiroplasma infections in tabanid (Diptera: Tabanidae) flies. IOM Lett. 2:114.

6. French, F. E., R. F. Whitcomb, J. G. Tully, K. J. Hackett, E. A. Clark, R. B. Henegar, and D. L. Rose. 1990. Tabanid spiroplasmas of the southeast USA new groups and correlation with host life history strategy. Zentralbl. Bakteriol. Suppl. 20:919-921.

7. French, F. E., R. F. Whitcomb, D. L. Williamson, and R. B. Henegar. 1996. Spiroplasmas of Tabanus lineola. IOM Lett. 4:211-212.

8. Hackett, K. J., and T. B. Clark. 1989. Ecology of spiroplasmas, p. 113-200. In R. F. Whitcomb and J. G. Tully (ed.), The mycoplasmas, vol. 5. Academic Press, San Diego, Calif

9. International Committee on Systematic Bacteriology Subcommittee on the Taxonomy of Mollicutes. 1995. Revised minimal standards for descriptions of new species of the class Mollicutes. Int. J. Syst. Bacteriol. 45:605-612.

10. Konai, M., E. A. Clark, and R. F. Whitcomb. 1992. Temperature ranges, growth optima, and growth rates of Spiroplasma (Spiroplasmataceae: class Mollicutes) species. Curr. Microbiol. 32:1-7.

11. Konai, M., R. F. Whitcomb, and M. Camp. 1994. Growth of spiroplasmas at the upper temperature range limit. IOM Lett. 3:527-528.

12. Markham, P. G., T. B. Clark, and R. F. Whitcomb. 1983. Culture techniques for spiroplasmas from arthropods. Methods Mycoplasmol. 2:217-223.

13. Rose, D. L., J. G. Tully, J. M. Bové, and R. F. Whitcomb. 1993. A test for measuring growth responses of mollicutes to serum and polyoxyethylene sorbitan. Int. J. Syst. Bacteriol. 43:527-532.

14. Tully, J. G. 1983. Cloning and filtration techniques for mycoplasmas. Methods Mycoplasmol. 1:173-177.

15. Tully, J. G. 1995. Determination of cholesterol and polyoxyethylene growth requirements of mollicutes, p. 381-389. In S. Razin and J. G. Tully (ed.) Molecular and diagnostic procedures in mycoplasmology, vol. 1. Academic Press, San Diego, Calif.

16. Tully, J. G., and S. Razin (ed.). 1996. Appendix, p. 460-462. In S. Razin and J. G. Tully (ed.) Molecular and diagnostic procedures in mycoplasmology, vol. 2. Academic Press, San Diego, Calif.

17. Tully, J. G., and R. F. Whitcomb. 1991. The genus Spiroplasma, p. 1960 1980. In A. Balows, H. G. Trüper, M. Dworkin, W. Harder, and K. H Schleifer (ed.), The prokaryotes, 2nd ed., vol. 2. Springer-Verlag, New York, N.Y.
18. Tully, J. G., J. M. Bové, F. Laigret, and R. F. Whitcomb. 1993. Revised taxonomy of the class Mollicutes: proposed elevation of a monophyletic cluster of arthropod-associated mollicutes to ordinal rank (Entomoplasma tales ord. nov.), with provision for familial rank to separate species with nonhelical morphology (Entomoplasmataceae fam. nov.) from helical species (Spiroplasmataceae), and emended descriptions of the order Mycoplasmatales, family Mycoplasmataceae. Int. J. Syst. Bacteriol. 43:378-385.

19. Tully, J. G., D. L. Rose, E. Clark, P. Carle, J. M. Bové, R. B. Henegar, R. F. Whitcomb, D. E. Colflesh, and D. L. Williamson. 1987. Revised group classification of the genus Spiroplasma (class Mollicutes), with proposed new groups XII to XXIII. Int. J. Syst. Bacteriol. 37:357-364.

20. Whitcomb, R. F. 1983. Culture media for spiroplasmas. Methods Mycoplasmol. 1:147-158.

21. Whitcomb, R. F., and K. J. Hackett. 1996. Identification of spiroplasma from insects, p. 313-322. In J. G. Tully and S. Razin (ed.), Molecular and diagnostic procedures in mycoplasmology, vol. 2. Academic Press, San Diego, Calif.

22. Whitcomb, R. F., F. E. French, and R. B. Henegar. Unpublished data

23. Whitcomb, R. F., K. J. Hackett, J. G. Tully, E. A. Clark, F. E. French, R. B Henegar, and D. L. Rose. 1990. Tabanid spiroplasmas of the southeastern USA: new groups, and correlation with host life history strategy. Zentralbl. Bakteriol. Suppl. 20:441-444.

24. Whitcomb, R. F., K. J. Hackett, J. G. Tully, E. A. Clark, F. E. French, R. B. Henegar, D. L. Rose, and A. G. Wagner. 1990. Tabanid spiroplasmas as model for mollicute biogeography. Zentralbl. Bakteriol. Suppl. 20:931-933.

25. Whitcomb, R, F, D. L. Williamson, J. M. Bové, F. E. French, M. Konai, G. Gasparich, M. Abalain-Colloc, C. Saillard, C. Chastel, E. A. Clark, P. Carle, D. L. Rose, R. B. Henegar, and K. J. Hackett. 1992. Revised classification of spiroplasmas. IOM Lett. 2:134.

26. Williamson, D. L., J. G. Tully, and R. F. Whitcomb. 1989. The genus Spiro plasma, p. 71-111. In R. F. Whitcomb and J. G. Tully (ed.), The mycoplasmas, vol. 5. Academic Press, San Diego, Calif.

27. Williamson, D. L. 1983. Specialized electron microscopic techniques for spiroplasmas in plant and insect tissues. Methods Mycoplasmol. 1:71-76.

28. Williamson, D. L., J. G. Tully, and R. F. Whitcomb. 1979. Serological relationships of spiroplasmas as shown by combined deformation and metabolism inhibition tests. Int. J. Syst. Bacteriol. 29:345-351.

29. Williamson, D. L., R. F. Whitcomb, and J. G. Tully. 1978. The spiroplasma deformation test, a new serological method. Curr. Microbiol. 1:203-207.

30. Williamson, D. L., J. G. Tully, L. Rosen, D. L. Rose, R. F. Whitcomb, M.-L Abalain-Colloc, P. Carle, J. M. Bové, and J. Smyth. 1996. Spiroplasma diminutum sp. nov., from Culex annulus mosquitoes collected in Taiwan. Int J. Syst. Bacteriol. 46:229-233. 